\title{
Література:
}

1. Терлюк I. Я. Огляд історії кримінального права України : навчальний посібник. Львів: Ліга-Прес, 2007. 92 с.

2. Ухач В. 3. Історія держави і права України : навчальний посібник (конспекти лекцій). Тернопіль: Вектор, 2011.378 с.

DOI https://doi.org/10.30525/978-9934-26-074-2-47

\section{ПРОБЛЕМНІ ПИТАННЯ РОЗВИТКУ КРИМІНАЛЬНОГО ЗАКОНОДАВСТВА У СФЕРІ ПРОТИДІЇ БУЛІНГУ}

\author{
Ільїна О. В. \\ кандидат юридичних наук, доиент, \\ дочент кафедри кримінально-правової політики \\ та кримінального права \\ Київського начіонального університету імені Тараса Шевченка \\ м. Київ, Украӥна
}

Конституція України проголосила «людину, іiі життя і здоров’я, честь і гідність, недоторканність і безпека найвищою соціальною цінністю. Права і свободи людини та їх гарантії визначають зміст і спрямованість діяльності держави. Держава відповідає перед людиною за свою діяльність. Утвердження і забезпечення прав і свобод людини є головним обов'язком держави» (ст. 3) [1]. Оскільки Конституція України має свою силу на всій території України та стосується всіх ії̈ громадян, можна 3 упевненістю сказати, що людина як найвища соціальна цінність має захищатися у всіх сферах ії життя: побутовому, соціальному, правовому. Що стосується соціального життя людини та ії комунікацій з іншими особами, вважаємо за необхідне згадати ст. 28 Основного Закону: «кожен має право на повагу до його гідності. Ніхто не може бути підданий катуванню, жорстокому, нелюдському або такому, що принижує його гідність, поводженню чи покаранню [1]. Цитована стаття набуває особливого значення в сучасних умовах підвищення рівня підліткової агресії. Вчені наводять статистику, що «за даними Всесвітньої організації охорони здоров'я, Україна посідає четверте місце в світі за рівнем підліткової агресії, поступаючись лише Росії, Албанії та Білорусі» [2, с. 107].

Звертаючись до тлумачення терміну «булінг», вчені визначають, що він означає «цькування, залякування, агресивне переслідування одного 3 членів колективу з боку інших представників колективу» [2, с. 108]. «Булінг може проявлятись у вигляді психологічного тиску (образи, 182 
приниження, погрози, ігнорування тощо) та фізичних знущань (удари, поштовхи, принизливий фізичний контакт, побиття та інше). Не рідко фізичний і психологічний тиск об'єднуються» [3]. Продовжуючи дослідження, варто зауважити, що термін «булінг» віднедавна став не тільки науковим або соціальним терміном, але і законодавчим.

Якщо спроектувати зроблені висновку у площину Кримінального кодексу України, то слід звернути увагу на такий склад кримінального правопорушення як катування: «Катування, тобто умисне заподіяння сильного фізичного болю або фізичного чи морального страждання шляхом нанесення побоїв, мучення або інших насильницьких дій 3 метою примусити потерпілого чи іншу особу вчинити дії, що суперечать їх волі, у тому числі отримати від нього або іншої особи відомості чи визнання, або з метою покарати його чи іншу особу за дії, скоєні ним або іншою особою чи у скоєнні яких він або інша особа підозрюється, а також 3 метою залякування чи дискримінації його або інших осіб» (ч. 1 ст. 127) [4]. Визначальною ознакою, яка є дуже схожою із характеристикою булінгу, на наш погляд, є заподіяння морального страждання шляхом насильницьких дій. Зрозуміло, що насильницькі дії можуть бути різного характеру, і не обов' язково це має бути фізичний вплив на особу. Фактично ми ведемо мову про те, що окремі прояви булінгу підпадають під визначення катування.

Окрім цього, як вже зазначалося, наслідком булінгу іноді стає самогубство, у зв’язку із чим слід звернути увагу на ч. 1 ст. 120 Кримінального кодексу України «доведення до самогубства: доведення особи до самогубства або до замаху на самогубство, що $є$ наслідком жорстокого з нею поводження, шантажу, систематичного приниження іiі людської гідності або систематичного протиправного примусу до дій, що суперечать іiі волі, схиляння до самогубства, а також інших дій, що сприяють вчиненню самогубства» [4]. В даному складі кримінального правопорушення як наслідок булінгу може бути шантаж, систематичне приниження людської гідності. Фактично в цьому складі кримінального правопорушення може йти мова про булінг, який став причиною вчинення самогубства.

Як зазначають вчені, «таке кримінальне правопорушення як шантаж також доцільно відносити до психологічних катувань, адже він реалізується шляхом погрози, умовою не втілення в життя якої є вдавання потерпілого до певного вчинку» [2, с. 108]. Однак, варто пояснити, що такий склад кримінального правопорушення як «шантаж» відсутній у сучасному Кримінальному кодексі України. Цей термін міститься у інших складах кримінального правопорушення, зокрема, у ст. 120 «доведення до самогубства», ст. 149 «торгівля людьми», ст. 258-1 
«втягнення у вчинення терористичного акту», ст. 303 «сутенерство або втягнення особи в заняття проституцією» [4].

Також вважаємо за доцільне звернути увагу на такий склад правопорушення як «хуліганство, тобто грубе порушення громадського порядку 3 мотивів явної неповаги до суспільства, що супроводжується особливою зухвалістю чи винятковим цинізмом» [4]. Як свідчить практика, булінг досить часто кваліфікується саме за цим складом кримінального правопорушення.

Не можна залишити поза увагою склад кримінального правопорушення, передбачений ст. 166 Кримінального кодексу України «злісне невиконання обов'язків по догляду за дитиною або за особою, щодо якої встановлена опіка чи піклування». Фактично у даному складі кримінального правопорушення йдеться про відповідальність батьків за вчинення їх дітьми протиправних дій, зокрема, булінгу.

Щодо суб'єктного складу названих кримінальних правопорушень, слід звернути увагу на те, що «булінг» визначається як протиправна діяльність дітей шкільного віку. Водночас, відповідальність за кримінальне правопорушення у формі катування несуть особи у віці від 16 років. За статтею 120 «доведення до самогубства» відповідальність настає також лише 316 років. I лише за вчинення хуліганства відповідальність настає 314 років. Такий висновок грунтується на аналізі ст. 22 Кримінального кодексу України «вік, 3 якого може наставати кримінальна відповідальність», за якою за загальним правилом «кримінальній відповідальності підлягають особи, яким до вчинення кримінального правопорушення виповнилося шістнадцять років» и лише у виключному переліку випадків передбачена відповідальність 314 до 16 років [4]. Тобто наразі склалася проблемна ситуація: з одного боку булінг - це проблема саме школярів; 3 іншого - кримінальна відповідальність за вчинення дій, що фактично становлять собою булінг настає у більшості випадків 316 років, коли школярі переважно закінчують школу. Вважаємо що проілюстрована ситуація має якнайшвидше вирішитися на законодавчому рівні. На наш погляд, рішенням може бути закріплення в Кримінальному кодексі України складу кримінального правопорушення «булінг», який буде відрізнятися за тяжкістю наслідків від аналогічного адміністративного складу правопорушення.

\section{Література:}

1. Конституція України. Офіційний вісник України. 2010. № 72/1. С. 15. Ст. 2598. 
2. Соціальна та кримінально-правова характеристика булінгу. Науковий вісник Херсонського державного університету. 2018. Вип. 3. Том 2. С. 107-110.

3. Що таке «булінг» та чому про нього треба знати всім батькам: пояснюють у центрі соціальних служб. URL: https://bilyayivka.city/ $\mathrm{read} /$ card/3080/scho-take-buling-ta-chomu-pro-nogo-treba-znati-vsim-batkampoyasnyuyut-u-centri-socialnih-sluzhb (дата звернення: 28.07.2019).

4. Кримінальний кодекс України: Кодекс України, Кодекс, Закон від 05.04.2001 № 2341-III. Відомості Верховної Ради Украӥни (ВВР). 2001. № 25-26. Ст. 131.

DOI https://doi.org/10.30525/978-9934-26-074-2-48

\title{
ПИТАННЯ КРИМІНАЛІЗАЦІЇ ПОРУШЕННЯ САНІТАРНИХ ПРАВИЛ І НОРМ ЩОДО ЗАПОБІГАННЯ ІНФЕКЦІЙНИМ ХВОРОБАМ В УМОВАХ ПАНДЕМІЇ COVID-19
}

\author{
Козерацька О. С. \\ старший викладач кафедри кримінального права, \\ кримінального прочесу та криміналістики \\ Одеського національного університету імені I. I. Мечникова \\ м. Одеса, Україна
}

Стрімке поширення світом гострої респіраторної хвороби COVID-19, спричиненої коронавірусом SARS-CoV-2 (далі - пандемія COVID-19), призвело до величезних економічних і людських втрат, що спонукало держави вжити радикальних заходів щодо захисту громадського здоров'я. Масштаби розповсюдження і ступінь тяжкості пандемії COVID-19 досягли такого рівня, коли, з точки зору охорони громадського здоров'я, деякі держави були вимушені ввести режим надзвичайного стану, як це передбачено національними конституційними нормами та відповідними Законами.

Урядами багатьох країн світу, 3 метою запобігання поширенню коронавірусної інфекції COVID-19, встановлено жорсткий карантин та запроваджено обмежувальні протиепідемічні заходи. Соціальне дистанціювання, режим самоізоляції, що представляють собою основну захисну міру по боротьбі з вірусом, та інші карантинні заходи, які були введені для стримування пандемії COVID-19, суттєво вплинули на світову економіку. Закриття магазинів, ресторанів і підприємств, що не 